A P

1
21
$L 5$

UC-NRLF :

IIII (I) I I I I

c 2676279

O)

n

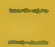

$\infty$ 


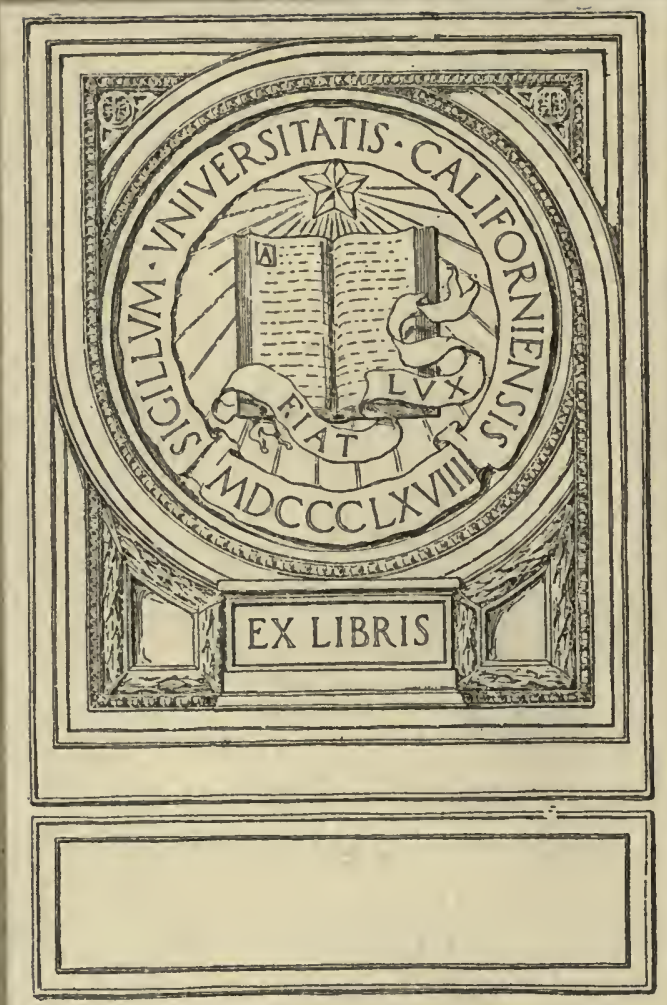


Final Report of the Library Association Technical and Commercial Libraries Committee

APPENDIX A

\title{
CLASS LIST
}

$\mathrm{OF}$

\section{CURRENT SERIAL DIGESTS AND INDEXES \\ OF THE}

\section{LITERATURE OF SCIENCE, TECHNOLOGY AND COMMERCE}

\author{
THE LIBRARY ASSOCIATION \\ CAXTON HALL, WESTMINSTER \\ S.W. I \\ 6 NovвмввR, I9I 7 \\ Price: One Shilling
}



Final Report of the Library Association Technical and Commercial Libraries Committee APPENDIX A

\section{CLASS LIST}

Or

\section{CURRENT SERIAL DIGESTS AND INDEXES OF THE}

LITERATURE OF SCIENCE, TECHNOLOGY AND COMMERCE

THE LIBRARY ASSOCIATION

CAXTON HALL, WESTMINSTER

S.W. I

6 November, I9I7 


$$
\begin{aligned}
& A F 1 \\
& 21 \\
& 45
\end{aligned}
$$




\section{KEY TO CLASSIFICATION.}

AGRICULTURE, $S$.

Anatomy, QM.

Anthropology, GN.

Artificial (Imitation) Substances, TP 995.

Astronomy, QB.

BACTERIOLOGY, QR.

Bibliography, National, AC.

- Universal, AA-AB.

Book Selection Technology, $T$.

Brewing, TP 570.

Ceramics, TP 785 .

Chemical Technology, TP.

Chemistry, QD.

- Analytical, QD 70.

- Physical, QD 450.

Coal Mining, TN 802 .

ECONOMICS, HB.

Education, L.

Electrical Engineering, TK.

Engineering, TA.

Entomology, QL.

Eugenics, $\mathrm{HQ}$.

FACTORY Organisation, TA.

GAS Manufacture, TP 700.

Geography, G.

Geology, QE.

Glass Making, TP 845 .

IndeXes [to Periodicals], Al.

Iron and Steel, TS 300.

Legislation, $\mathrm{KZ}$.

Leather Manufacture, TS 940.

Lighting, Artificial, TP 700.

MEDICINE, $R$.

Metallography, TN 690.

Metallurgy, TN 600 .

- Iron, TS 300.

Microscopy, QH 201.

Military Science, U.

Mineral Industries, TN.

Municipal Administration, HD.

['APERMAKING, TS IO80.

Pathology, Plant, SB 509.

Periodicals, Indexes, AI.

- Union Lists, AA.

Philosophical Instruments, Q 184.

Photography, TR.

Physical Chemistry, QD 450.

Physics, OC.

Physiology, Animal, QP.

Plant Pathology, SB 509 .

Press Directories, AC 50 .

Public Documents, AD.

RADIOACTIVITY, QC 475.

Radiotelegraphy, TK 570.

SCIENCE, $Q$.

Scientific Instruments, $Q \mathbf{1 8 4}$.

- Management, TA.

TECHNOLOGY, T.

Textiles, TS I 300.

WAste Utilization, TP 995.

LABOUR, HD

Law, K.

Wireless Telegraphy, TK 570. 
Digitized by the Internet Archive in 2008 with funding from Microsoft Corporation 


\section{CLASS LIST}

of

\section{CURRENT SERIAL DIGESTS AND INDEXES}

OF THE

\section{LITERATURE OF SCIENCE, TECHNOLOGY, AND COMMERCE}

N.B. - The List represents the minimum bibliographical equipment of a library professing to specialize in any of the following departments of knowledge. It is a selection from the "Class Catalogue of Current Serial Digests, etc.," issued by the Library Association in 1912, revised and extended. The classification is that of the Library of Congress, except that Z Bibliography has been transferred to A. As a rule German periodicals have been included only where no suitable substitute in another language could be found.

\section{AA.-Universal Bibliography.}

\section{Union Lists of Periodicals.}

As there is no printed Union List of Periodicals of the United Kingdom, information must be sought in (i) the lists prefixed to the Subject Indexes, $1800-1900$, published by the Royal Society (B.J. Q) : (ii) the local Union Lists published by Manchester (1898); Cambridge (1906-1914), and Oxford (1913); (iii) the catalogues of periodicals published by various institutions, €.g. the British Museum; Royal Society; London University; Patent Office, etc. Where these sources fail, application should be made to the Keeper of the Printed Books, British Museum, for the desired information.

\section{AB.-Universal Bibliography.}

Library Catalogues. British Museum. Subject Index of the Modern Works added to the Library. Ed. G. K. Fortescue. Vol. I-3, 1881-1900. Continued quinquennially, 1901-5 (1906); 1906-10 (1911).

Imp. 8vo. In progress.

The work is supplementary to "The Catalogue of Printed Books" for the period covered by the two publications.

Patent Office Library. Subject Lists. (List free on Application.)
6 . each.

These are valuable for the earlier literature and for their analytical references to foreign periodicals. Supplementary information to date in specified headings in these lists can be obtained on application to the Librarian of the Patent Office. 


\section{AC. - National Bibliographies.}

Foreign. Hinrichs (weekly, half yearly, and quinquennially) for books in the German language, Lorenz and "La Bibliographie de la France" for French books and the "American Catalogue" and the "Cumulative Book Index" for American books are the three most important foreign bibliographies. Sets of the above publications are expensive and difficult to procure. For more detailed information consult R. A. Peddie's “National Bibliographies” (Grafton, 1912).

\section{AC 50.-Press Directories.}

United Kingdom. Willing, Is. Mitchell, 2s.

France. Le Soudier (H.). Catalogue-Tarif des Journaux Publics à Paris.

Germany and Austria-Hungary. Deutscher Zeitschriften-Katalog.

Switzerland. Annuaire de l'Association de la Presse Suisse.

Zurich, O. Füssli. 8 mks.

United States and Canada. Severance (H. O.). A Guide to the Current Periodicals and Serials of the United States and Canada. 3 rd ed. 1914. Ainn Arbor, G. Wahr. \$2.50.

Only the latest issues of these publications are, as a rule, required in practice.

AD.-Public Documents. See also KZ Legislation.

Stationery Office. (i) List of Parliamentary Publications; (ii) List of Official Publications.

London.

Issued Monthly, with Quarterly and Annual Consolidations.

N.B.-The literature of Public Documents is, as a rule, not included in the National Bibliographies.

United States. Superintendent of Documents. Catalogue of the Public Documents of Congress and of all Departments of the Government of the United States.

Washington, Govt. Printing Office.

Known as the "Comprehensive Index". Eleven volumes bave been published to June, $\operatorname{rg}_{3}$ (rgr5). The work is in "dictionary" catalogue form, and is a valuable source of reference on all questions of trade, economics, science, and technology.

Monthly Catalogue (The). The United States Public Documents.

Also issued by the Superintendent of Documents. Forms a continution to the above work.

\section{Al.--Indexes. See also T Technology.}

Athenzeum Subject Index to Periodicals. Issued at the request of the Council of the Library Association. I9I 5, etc.

Athenæum Office, Breams Buildings. $£_{2}$ ros.

Indexes over 500 periodicals, a large number of which are scientific or technological in character. The articles indexed are obtainable by subscribers on loan. The Annual Volumes are preceded by a series of Class Lists which are sold at prices ranging from 6 d. to 55 . each.

\section{G.-Geography.}

Bibliographie Géographique annuelle.

Geographical Record. Formerly the Bulletin of the Ams, Colin

phical Society. New York, Broadway, 156th Street. reviews.

Includes classified abstracts of current geographical papers, maps, and book 


\section{HB.-Economics.}

American Economic Review, published by American Economic Association Cambridge, Mass. Quarterly, \$1'25.

Contains full annotated bibliography of articles on economics, classified under main headings.

\section{HD.-Economics of Production (For Scientific Management.} See TA Engineering).

Bulletin of the International Labour Office. (Monthly.)

$$
\text { Woolwich, Pioneer Press. 8s. yearly. }
$$

Ccntaias text of new labour laws in all countries, surnmaries of various decrees, and the war emergency legislation of the belligerent countries, generally with texi.

\section{HD.-Municipal Administration.}

Special Libraries.

Indianapolis, Special Libraries Association. \$2.00.

Deals with the progress of technical, professional, and business libraries. Each number contains a special bibliography. A set of the publication is in the L.A. I.ibrary at the London School of Economics.

\section{HF.-Commerce.}

Business Digest. (Weekly, with Quarterly consolidated volume, entitled "Current Business Encyclopædia ".)

Nerv York, Cumulative Digest Corporation. \$15; weekly or quarterly alone, \$10.

\section{HQ.-Eugenics.}

Eugenics Review. Published Quarterly by the Eugenics Education Society, Kingsway House. Kingsway, W.C. Is. net.

Contains digest of English and foreign periodical literature, usually arranged under subject headings suggested by the articles.

\section{K.-Law.}

Index to Legal Periodicals and Law Library Journal.

Athenæum Office, Breams Buildings, W.C. $\complement_{1}$ yearly. Sets vol. I-8, 1908-15. $£ 6$ 5s., carriage free.

Indexes about 80 professional journals, British and American.

\section{KZ.-Legislation.}

Society of Comparative Legislation Journal. (Quarterly.)

J. Murray. 5s. net.

Apart from its original papers on Comparative and International Law, the journal is valuable for its digest of British and Foreign Legislation issued under the tille of "Review of Legislaiion" and separately indexed. In no other publication can the progress of legislation in a given country be so readily ascertained.

New Statesman. Blue Book supplement.

Issued three or four times a year, and containing complete annotated list of British parliamentary publications, in classified order. 


\section{L.-Education.}

United States. Bureau of Education. [Annual] Bibliography of Education.

Superintendent of Documents. 20 cents. tions".

The Bureau also publishes a "Monthly record of current educational publica.

\section{Q.-Science.}

Royal Society of London. Subject Index to the Catalogue of Scientific Papers, 1800-1 900.

Vol. I. Pure Mathematics (1908).

2. Mechanics (1909).

3. Physics. Part I. Generalities, Heat, Light, Sound (1912).

2. Electricity and Magnetism (I9I4).

Valuable chiefly for historical research. It was proposed to publish Subject Indexes for each of the seventeen schedules of the International Catalogue. It is now doubtful whether the original proposals will be carried out. Union Lists of Periodicals showing the principal libraries in the United Kingdom in which sets of a given publication can be consulted are prefixed to each volume.

International Catalogue of Scientific Literature. Published for the International Council by the Royal Society of London.

London, Harrison.

Published annually in seventeen sections at $£_{1} 8$ the set. The sections arranged in the order of the Library of Congress classification are :-

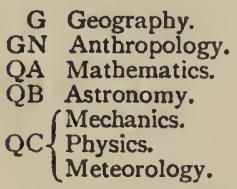

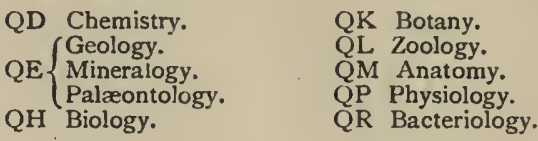

Each of these sections is sold separately. This work comprises the scientific literature-text-books, dissertations, and periodicals- of the world. The first annual issue deals with the literature of rgor. It forms an annual continuation of the author and subject "Catalogue of Scientific Papers," in course of publication by the Royal Society; of which thirteen volumes of the Author Catalogue have been issued for 1800 83 ; and of which $188_{4}-1900$ is now nearly completed.

\section{Q 184.-Philosophical Instruments.}

Zeitschrift für Instrumentenkunde. (With supplement Deutsche Mechaniker-Zeitung.) (Monthly.) Berlin, Springer. 24 mks.

Publishes full "Referate".

\section{QC.-Physics.}

Science Abstracts. A. Physics. (Monthly.)

London, Spon. 1s. 6d. per number. Subscription to A and B. Electrical Engineering, 30s.

Very full abstracts, with occasional illustrations, issued by the Institution of Electrical Engineers in association with the Physical Society of London, and with the co-operation of the American Physical Society, the American Institute of Electrical Engineers, and the Assoziazione Elettrotecnica Italiana.

\section{QC 475.-Radioactivity.}

Jahrbuch der Radioaktivitat und Elektronik. (Four parts yearly.)

$$
\text { Leipzig, S. Hirzel. } 20 \mathrm{mks} \text {. }
$$


QD Chemistry.-See also TP Chemical Technology. American Chemical Society. Chemical abstracts. (Fortnightly.)

The Society. $\$ 6$.

Illustrated abstracts classified under thirty headings. These abstracts cover a wider technological field than that of the European chemical societies. They include abstracts of the patents of the leading industrial countries.

Chemical Society of London. Journal (transactions and abstracts).

London, Gurney \& Jackson. 4as.

Monthly. Abstracts form two volumes yearly.

\section{QD 70.-Analytical Chemistry.}

Analyst. The organ of the Society of Public Analysts. (M.)

Simpkin, Marshall. 25.

Contains full abstracts of the papers published in other journals.

QC.

Transactions of the Optical Society.

39 Victoria Street, S.W., I.

Includes abstracts.

\section{QD 450.-Physical Chemistry.}

Zeitschrift für Physikalische Chemie.

$$
\text { Leipzig, Engelmann. } 22 \text { mks. per vol. }
$$

Original papers published in German language.

\section{QE.-Geology.}

Geological Literature added to the Geological Society's Library. . . .

Geological Society, Burlington House. 2 s.

Annual. Consists of a list of the journals and other publications received by the Society, with an analytical author and subject index thereto. Libraries should acquire sets of this publication.

\section{QH 201.-Microscopy.}

Royal Microscopical Society. Journal (Bi-Monthly).

20 Hanover Square, W. 6s. per part.

Publishes an annual summary of current researches relating to Zoology, Botany (principally invertebrata and cryptogamia), Microscopy, etc.

Zeitschrift für wissenschaftliche Mikroskopie und für mikroskopische Technik. Leipzig, Hirzel. 20 mks.

Publishes full abstracts and bibliography.

\section{QL.-Entomology.}

Review of Applied Entomology. Series A, Agricultural. Series B, Medical and Veterinary. Issued by the Imperial Bureau of Entomology.

89 Queen's Gate, S.W. I2s. ; or A, 8s. and B, 5s. yearly.

$$
\text { QP.-Physiology : Animal. }
$$

Physiological Abstracts. Issued by the Physiological Society (Great Britain and Ireland) and the American Physiological Society.

Begins with the literature of rgr6. 


\section{QR.-Bacteriology.}

Abstracts of Bacteriology. Bi-monthly.

Cambridge, University Press. 23 s.

Published by the Society of American Bacteriologists. Intended to replace the "Centralblatt" for English readers.

\section{R.-Medicine.}

Index Medicus. A monthly classified record of the current medical literature of the world. Second series.

Washington, Carnegie Institution, etc. $\$ 8.60$.

\section{S.-Agriculture.}

Agricultural Index.

New York, Wilson Co. \$8. Indexes 158 agricultural journals and bulletins.

Experiment Station Record. (Monthly.) 2 vols. yearly.

Washington, Govt. Printing Office. \$1.50 each vol.

Consists of classed abstracts of all U.S. Experiment Stations with some foreign material. Excellent author and subject indexes. Taking price into consideration, this is the cheapest and best resume of the progress of agricultural science published.

Imperial Institute. Bulletin. J. Murray, Ios. yearly.

Includes abstracts on tropical agriculture and the commercial utilization of the natural products of British Dependencies.

\section{SB 509.-Plant Pathology.}

Zeitschrift für Pflanzenkrankheiten.

Stuttgart, Ulmer. 20 mks.

\section{T.-Technology: Book Selection.}

Technical Book Review Index. Vol. I, No. 4, July, 1917, etc.

Pittsburg, Carnegie Library.

The first three numbers were issued in the Monthly Bulletin of the Carnegie Library. In view of the growing importance of American Technological literalure the work is likely to be of great value for book selection.

\section{T.-Technology : Periodical Indexes.}

Association de Documentation Bibliographique, Scientifique, Industrielle et Commerciale. Bulletin. (5 Nos. yearly.)

82, Rue Taitbont, Paris. (Subscription on application.)

The Bulletin contains classified references to technical articles in periodicals and bibliographies with other useful information. No. $59 \cdot 60$ contains an Index to $191 \mathrm{r}-15$. Industrial Arts Index.

Niw York, H. W. Wilson Co. Subscription on application.

Indexes about seventy technical periodicals, mostly American.

\section{TA.-Engineering.}

Engineering Index. Annual.

New York, Engineering Magazine Co. Ios.

Descriptive entries indicating length of article, classified alphabetically under eight main divisions. About 200 publications analysed. Compiled from the monthly numbers of "Industrial Management" (formerly the "Engineering Magazine"). This work supplements "The Athenzum Subject Index" which so far as possible coordinates its work with that of the above publication. 


\section{TA.--Engineering (continued).}

American Society of Mechanical Engineers. Journal. (Monthly.)

The Society, 29 West 39 th Street, New York. \$4.

"Review of Engineering Periodicals." Consists of illustrated abstracts. This is followed by a classified list of "Selected tirles of Engineering Articles".

Cassier's Engineering Monthly.

Cassier Co. $12 \mathrm{~s}$.

Includes Cassier's Engineering abstracts. These are not cumulative or indexed at the end of the year. They include the subject of "Scientific Maragement".

\section{TK.-Electrical Engineering.}

Science Abstracts. B, Electrical Engineering. (Monthly.)

See above QC Physics.

$$
\text { London, Spon. is, 6d. per number. }
$$

\section{TK 570.-Wireless Telegraphy.}

Year Book of Wireless Telegraphy and Telephony (The).

Wireless Press Ltd., Museum House. 3s. 6d. net.

Useful reference work for the Laws and Regulations, Stations, Patents, and general development of Wireless Communication.

\section{TN.-Mineral Industries.}

Mineral Industry: its statistics, technology, and trade.

$$
\text { New York, McGraw Hill Book Co. \$5. }
$$

Covers the whole of the useful metals and minerals, and includes general metal. lurgical processes. Chapters often contain excellent bibliographies. Indispensable in any library where mining or metallurgical information is required.

\section{Mining World. \\ Chicago, Mining World Co. 83.}

Indexcs of current literature (half-yearly). A consolidation of the weekly issues in the Mining World. A price is quoted against the articles indexed. The publication is remarkable for the completeness with which it covers its specific field.

\section{TN 600.-Metallurgy.}

Institute of Metals. Journal (two vols. yearly).

Westminster, Caxton House. ¿I is.

Section 2 in these volumes consists of abstracts of papers relating to the Nonierrous Metals and Alloys.

Metal Industry. (Weekly.) London, 33 Bedford Street, W.C. 4d. net.

Since August, Igr2, has published a bibliographical section entitled " Recent Literature relating to Non-ferrous Metals ". Quotes price for articles indexed.

Revue de Métallurgie. Tome I, Mémoires; Tome I, bis Extraits.

Paris, Dunod \& Pinat. 40 frs.

The extracts form an annual volume of about 800 pages, fully illustrated.

\section{TN 690.-Metallography.}

Internationale Zeitschrift für Metallographie. (4-5 Nos. yearly.) Leipzig, Borntraeger.

Original papers in the languages of the originals. 


\section{TN 802.-Coal Mining.}

Colliery Guardian. (Weekly.)

London, 30-3 I Furnival Street, E.C. 5d. per number.

From 4 April, I9II, has published a "monthly list of recent coal literature".

TP.-Chemical Technology.

Chemiker-Zeitung. (Tri-weekly.)

Coethen, the Journal. 5 mks. quarterly.

Weekly supplement, "Chemisch-Technisches Repertorium". EConsists of short classified abstracts of papers and German patents.

Society of Chemical Industry. Journal (fortnightly).

London, Vacher. $36 \mathrm{~s}$.

" Journal and Patent Literature." Publishes under twenty-four classes abstracts of all articles and patents relating to industrial chemistry.

Society of Chemical Industry. Reports of the progress of Applied Chemistry. Vol. I, I9I6.

London, Harrison. To members, 2s. 6d. ; non-members, 5s. net.

Contains reports on fifteen classes of chemical technology, with numerous references to original articles.

\section{TP 570.-Brewing.}

Institute of Brewing Journal, containing the transactions of the various sections, together with abstracts of papers published in other journals, etc. (Monthly.)

London, Harrison. 5s. per number.

\section{TP 700.-Gas Manufacture, Artificial Lighting, etc.}

Gas Age. (Formerly "Progressive Age".) (Fortnightly.)

Nere York, 52 Vanderbelt Avenue. \$3.

"Current Gas Literature." Alphabetical subject indexes published on the 16 th of each month and reprinted in the following issue in the advertisements for cutting up and pasting on cards.

American Gas Institute.

Nere York, 25 West 39th Street. \$5.

Abstracts. Has published since 1908 on separate slips ( $5 \times 8$ ins.) for filing in class order ( 108 classes) abstracts of papers and patents relating to the gas industry.

\section{TP 785.-Clay and Silicate Industries (Ceramics).}

English Ceramic Society: Transactions. Stoke-on-Trent. £I ros. materials.

Abstracts classified under eleven headings includes Glass, Cements, and Refractory

\section{TP 845.-Glass Making.}

Society of Glass Technology Journal. (Quarterly.)

Sheffield, Dr. W. E. S. Turner, $\chi_{\text {I Is. }}$

Contains classified abstracts from January, rgr 5. 


\section{TP 995.-Waste Utilization and Artificial (Imitation) Sub-} stances.

Kunst-Stoffe. (Fortnightly.)

Munich. I 3 mks, half-yearly.

Contains valuable original papers and digests of patents for the manufacture of artificial compounds.

Waste Trade World. (Weekly.) London. 6s. 6d. yearly.

\section{TR.-Photography.}

Jahrbuch für Photographie und Reproduktionstechnik. (Eder.)

Halle a S., Knapp. Bound in linen, $9.50 \mathrm{mks}$.

Besides original contributions the work contains a series of annual reports of the progress of Photography, Process Work, and Cinematography, fully supported by references to the literature of each year. It also contains German and Austrian patent and book lists.

\section{TS 300.-Iron and Steel, Metallurgy.}

Iron and Steel Institute. Journal (2 vols. yearly).

London, Spon. 16s. each vol.

Each vol. has a section, "Notes on the Progress of the Home and Foreign Iron and Steel Industries," consisting of classificd abstracts of recent fapers.

Stahl und Eisen. (Weekly.)

Diisseldorf, Verl. Stahleisen m. b. H. 15 mks. half-yearly.

Useful for German practice and patents.

TS 940.-Leather Manufacture.

Society of Leather Trades Chemists. Journal.

University, Leeds. £i $4 \mathrm{~s}$.

Anglo-French successor to the "Collegium". Contains abstracts of original paper and patent specifications.

\section{TS 1080.-Papermaking.}

Papermakers' Monthly Journal.

London, M. Singer \& Co. 6d. each number.

Commenced in April, 1912, "The Bibliography of Current Paper Trade Literature," prepared by the International Institute of Technical Bibliography.

\section{TS 1300.- Textiles.}

Textile Institute. Journal.

Manchester, 16 St. Mary's Parsonage. $£ 225$.

I915 volume contained a valuable classified list of articles and patents. This has been discontinued, but it is hoped to reinstate it in the journal at some future date.

\section{U.-Military Science.}

International Military Digest. A monthly cyclopæedia of current military progress.

Athenæum Office, Breams Buildings.

Monthly indexes, with quarterly and annual cumulations, $\mathfrak{E I}_{\mathbf{r}}$; monthly issues only, 12s. ; quarterly and annual issues only, 12s. A valuable source of information on the European War and professional topics. 



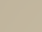

$$
\text { , n }
$$$$
\text { - }
$$ 



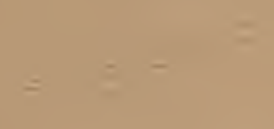

- 



\section{YD $\mid 1228$}

$398103 \quad \angle 5$

UNIVERSITY OF CALIFORNIA LIBRARY 
